\title{
Work-related stress impacts on the commitment of urban transit drivers
}

\begin{abstract}
This study uses structural equation modeling to test a model hypothesizing the impacts of overload and non-participation on job strain, turnover and commitment of urban transit drivers. The study sample comprises 331 responses from transit drivers from bus companies in Australia. The results show that nonparticipation has a direct and negative impact on organizational commitment while role overload has a direct and positive influence on intent to leave. An unexpected finding is that while overload and non-participation have significant positive impacts on job strain, there is no significant relationship between strain and organizational commitment. The implications are that work-related stressors appear to influence the organizational commitment and intent to leave of transit drivers directly rather than indirectly through job strain. Role overload and nonparticipation have not often been considered in the context of the commitment and intent to leave in stressful occupations such as urban transit driving.
\end{abstract}

Key words - job stress; role stress; stressors; job strain; commitment; overload; non-participation

\section{Introduction}


The link between stress and long-term ill health dates back to the early 1900s, with workrelated stress being predictive of a range of illnesses including heart disease, mental illness and other emotional issues (Cooper, 1983). Work-related stress has been described as the body's reaction to stressors such as daily work activities (Seyle, 1974) particularly around the relationship between what is demanded of workers and their ability to cope with these demands (Warren \& Toh, 1997). A widely accepted description of workrelated stress emanates from the work of Kahn et al., (1964) who described stress as the difference between worker satisfaction and the realities of the work situation. Other research by Indik et al., (1964) and McGrath (1976) has extended the notion of stress from the individual to the organization to reflect an environmental condition which demands a level of activity that threatens to exceeds an individual's capacity to meet that condition. Stressors include a range of work situations which hinder task performance due to the way in which work is organized or designed (Greiner, Ragland, Krause, Syme, \& Fisher, 1997). Stressors may be linked to role expectations, within which role overload (RO), role ambiguity (RA), role conflict (RC) and non-participation (NP) are prominent (Spector, Chen, \& O'Connell, 2000). Role overload describes a work situation where unreasonable expectations are held about either the quality or quantity of work (Dubinsky, Michaels, Kotabe, Lim, \& Moon, 1992). Role ambiguity describes a situation where an individual has inadequate knowledge or information to complete work (Dubinsky et al., 1992). Role conflict describes a situation where a worker is faced with incompatible expectations or demands which cannot be simultaneously achieved (Dubinsky et al., 1992). Non-participation relates to being expected to perform a role without being able to participate in decisions that affect the role (Beehr, Walsh, \& Taber, 1976). 
Research suggests (e.g. Carrere, Evans, Palsane, \& Rivas, 1991; Spector et al., 2000) that most models of stress show a link between job stressors and job strains. Stressors include variables such as RO, RA, RC mentioned above, while job strains are the reactions that employees have to job stressors, such as anxiety and frustration (Spector et al., 2000). Job strain has also been described as the outcome of high job demands together with low decision-making ability and control (Karasek, 1979). The importance of RO, RA, RC and NP as work-related stressors is underlined by numerous studies (e.g. Bech et al., 2005; Cooper, 1983; Dubinsky et al., 1992; Graham, Ramirez, Field, \& Richards, 2000) which identify them as major sources of occupational stress. At the organizational level work-related stress presents itself through high levels of absenteeism, high levels of turnover, increasing industrial relations issues and conflict (Cooper, 1983; Spector et al., 2000).

The link between role-related stressors, job strain and the health of employees has been established in a range of studies, for example: sleep deprivation in US workers (Knudsen, Ducharme, \& Roman, 2007); emotional exhaustion of hospital employees in Canada (Kelloway \& Barling, 1991); emotional exhaustion and diminished mental capacity in hospital and community nursing staff in the UK; decreased well-being in Danish Managers (Bech et al., 2005); and burnout in a study of medical practitioners (Graham et al., 2000). Other studies have identified the impact of role-stressors on organizational performance, for example: absenteeism in the Dutch army (Goedhard \& Goedhard, 2005); reduced job satisfaction and withdrawal (Schaubroeck, Cotton, \& Jennings, 1989); work performance in a cross-national study of industrial salespeople (Dubinsky et al., 1992); loss of productivity in a study of retail managers (Broadbridge, 
2002); and diminished organizational commitment in a study of transit drivers (Angle \& Perry, 1981). It appears that there is little evidence in the extant literature that investigates the impact of role stressors on job strain and organizational performance, particularly in transit operations in an Australian setting.

High levels of stress in transit drivers have been found to be associated with workrelated issues (Carrere et al., 1991; Chen \& Cunradi, 2008; Gardell, 1987). Few other professions are as stressful as urban transit driving. "Bus drivers in urban areas all over the world are exposed to a uniquely severe combination of occupational stressors" (Rydstedt, Johansson, \& Evans, 1998, p. 35). In a study of urban transit drivers elements of work have been identified as contributing to occupational stress. These include: a) traffic congestion; b) low or no input into how work is organized; c) time pressures; d) conduct of passengers; and e) work schedules (Evans, 1994). In an era of rapid technology updates, transit drivers may encounter another pressure from ticketing technology. The driver-public interactions may be more intensive when the electronic ticketing services are first launched to the public. Transit drivers have three primary tasks which often are contradictory: a) safety; b) the need to run to timetable; and c) displaying a professional and courteous manner in dealing with the public (Evans, 1994; Evans, Johansson, \& Rydstedt, 1999). The contradictory expectations facing transit drivers suggest that the bus industry has a number of unusual features (Angle \& Perry, 1981). One feature of the transit driver's job is the high levels of control imposed through the need to adhere to regulations, timetables and rosters. At the same time, interaction between the driver and passengers is solely at the discretion of the driver, while the amount of supervision of transit drivers is minimal. From the passengers' perspective the 
driver is the organization. The success or failure of an organization may depend on the job-related behavior of drivers (Angle \& Perry, 1981).

The negative effects of work-related role stress on job satisfaction are well established (e.g. Abdel-Halim, 1981; Schaubroeck et al., 1989; Yousef, 2002). The effects of rolestressors on organizational commitment (e.g. Addae, Parboteeah, \& Velinor, 2008; Harris, Artis, Walters, \& Licata, 2006; Qiang, Ragunathan, \& Ragunathan, 2001) and turnover (e.g. Glazer \& Beehr, 2005; Greiner, Krause, Ragland, \& Fisher, 2004; Greiner et al., 1997; Jones, Chonko, Rangarajan, \& Roberts, 2007; Lambert \& Hogan, 2008) have been researched across a range of industries. Given the susceptibility of transit drivers to workrelated stress, it is important for organizations to understand how stressors, in particular role stressors, impact on drivers' commitment and turnover intentions.

\section{Organizational commitment}

Organizational commitment has been the subject of organizational studies for over thirty years (Cappelli, 1999; Guest, 1998). Commitment has been described by DeCotiis and Summers (1987) as having important implications for both organizations and individuals, hypothesizing that it is a strong predictor of employee motivation and turnover. Steers

(1977) has argued that organizational effectiveness varies with the degree of organizational commitment displayed by employees. If organizational effectiveness does vary as Steers (1977) suggests then an understanding of the variables which influence commitment is necessary. Commitment research tends to be psychological in nature, focusing in the main on whether commitment is an attitude or a behavior. Two 
predominant views of commitment exist, affective and instrumental commitment (Angle \& Perry, 1981).

Affective commitment tends to focus on the organization, with the needs of the individual being satisfied by interaction with the organization. The result is that the individual increasingly identifies himself or herself with the organization while wishing to retain membership in order that the relationship may continue.

Instrumental commitment is based on a theory of organizational equilibrium, conditions under which an organization can induce its members to continue to participate (Barnard, 1938; March \& Simon, 1958). Each participant receives inducements from the organization in return for contributions made. Participation will only continue while inducements meet or exceed contributions, measured in terms of the values held by the participant. Increases in the differences between inducements over contributions decrease the propensity of an individual to leave. Decreases in the difference between inducements over contributions have the opposite effect. The exchange process leads to a bond between the employee and the organization, an instrumental form of commitment the strength of which depends on the strength of the bond between the parties (Penley \& Gould, 1988).

Penley and Gould (1988) have developed a model of commitment, based on Etzioni’s (1961) work in the area of organizational involvement, that represents the positive and negative aspects of affective commitment together with instrumental commitment. Positive affective commitment is termed moral commitment, typified by an acceptance of and identification with an organization's goals. Negative affective commitment is termed alienative commitment, typified by forced compliance and a lack of control of the work 
environment. Instrumental commitment is termed calculative commitment, typified by an exchange between an individual and the organization. Penley and Gould (1988) have developed a measure, the Organizational Commitment Scale (OCS), that represents each of the three elements of commitment. The elements measured by the OCS have been shown to be independent and reliable constructs.

\section{Hypotheses development}

When employees are not kept informed of important things happening in their company, they are unlikely to feel any ownership of decisions, such as decisions to change policies, that top management makes. Employees become more committed when they feel they "own" decisions. Allowing employees to participate in decision-making is likely to make them more receptive to the decision. For example, if employees are not allowed to participate in decisions about the need to keep to timetable, and the company keeps pushing them to meet targets, employees are likely to feel pressured to maintain timetables, thus causing job strain. Role stress theory suggests that role stress can lead to job strain (Mulki, Jaramillo, \& Locander, 2008). Non-participation, as one of the role stresses, may therefore cause job strain (Karasek, 1979; Spector et al., 2000). As nonparticipation rises, the level of job strain may also rise. Hence, we hypothesize that:

H1. Non-participation is a positive determinant of job strain. 
When employees are not told about important things that are happening in the company, a lower level of acceptance and identification with the organization's goals may occur. Likewise, employees may be reluctant to become involved in organizational events. In such cases, non-participation may decrease organizational commitment by reducing the perceived link between the employee's role and the accomplishment of the organization's goal (Dale \& Fox, 2008). Based on this, we hypothesize that:

\section{H2. Non-participation is a negative determinant of organizational commitment.}

In carrying out their tasks, employees often have to meet the expectations from other organizational members, which in turn may place unique demands on the employees (Mulki et al., 2008). The demands may lead to role stresses such as role overload. If employees face a large amount of workload, they may undergo a higher level of job strain, such as pressure and frustration. This is especially true when they are unable to finish the work within the designated timeframe. Research has suggested a positive relationship between role overload and job strain (Mulki et al., 2008; Richardson, Yang, Vandenberg, DeJoy, \& Wilson, 2008). Additionally, when unreasonable expectations are held about the quality of work, employees may feel less satisfied with work (Beehr et al., 1976), which in turn may lead to higher level of intention to leave (Chang, 2008). In such cases, role overload may increase employee turnover intentions. Thus, we hypothesize that:

\section{H3. Role overload is a positive determinant of job strain.}


H4. Role overload is a positive determinant of intent to leave.

In a workplace where employees feel bothered by being responsible for work tasks, they may not possess a sense of personal responsibility to help their organization achieve success. In such cases, job strain may decrease organizational commitment by reducing the perceived linkage between the employee's role and the acceptance of the organization's goals. Based on this, we hypothesize that:

H5. Job strain is a negative determinant of organizational commitment.

Employees who identify strongly with the organization's goals are more committed to the organization than those who have identify weakly. More committed employees show greater affection to their organization, which may result in longer tenure with the organization. Researchers (Chang, 2008; de Ruyter, Wetzels, \& Feinberg, 2001) have found a significant negative relationship between organizational commitment and turnover intentions. Thus, we hypothesize that:

H6. Organizational commitment is a negative determinant of intent to leave.

Figure 1 shows the hypothesized relationships between the constructs.

[Insert Figure 1 about here] 


\section{Data collection}

\section{Study context and participants}

The study is an investigation into the effect of role-stressors on the commitment of transit drivers in Australia. The bus industry in Australia comprises a mixture of governmentowned and privately-owned businesses. Fourteen bus companies representing a cross section of the industry were invited to participate in the study. Participation was anonymous and voluntary. A total of 940 questionnaires were distributed over a two month period, resulting in 331 completed responses, a response rate of $35 \%$.

Because of missing responses on the age question, the sample used for age analysis consisted of responses from 314 employees. The average employee age was 41 years old. With regard to the type of organization the sample was drawn from, 196 of the participants were private sector employees (59.2\%), while 135 were employees in the public sector $(40.8 \%)$.

\section{Measures}

Unless noted, all responses were made on a 5-point Likert scale ranging from 1 (strongly disagree) to 5 (strongly agree). Organizational commitment was measured by the five items in the OCS (Penley \& Gould, 1988), which are designed to measure moral commitment $(\alpha=.89)$. Example items are "I am dedicated to this company" and "Whenever I am in public I think of myself as an employee of this company". 
Four items measuring RO $(\alpha=.79)$ were selected from a larger number of items comprising the Job Related Tension Index (Kahn et al., 1964) and the Job Related Strain Index (Indik et al., 1964). An example item is "I find that I have extra work beyond what should normally be expected". Four items comprising the measure of NP $(\alpha=.78)$ were selected from a larger number of items developed by Pettegrew et al., (1980) based on research by Beehr et al., (1976). An example item is "I am able to influence what goes on in my company" (reverse scored).

Four items designed to measure job strain $(\alpha=.87)$ (defined as the extent to which drivers are affected by pressures peculiar to their job) were also included (e.g. I am bothered by having to keep order on school buses).

Intent to leave $(\alpha=.88)$ was measured with four items containing similar questions to those used by Weisberg (1994)and Meyer et al., (2004) in research into employee turnover. Example items are: "How frequently did you consider transferring to another job" and "How frequently did you consider changing the job itself". Responses were again made on a 5-point Likert scale ranging from 1 (Strongly Disagree) to 5 (Strongly Agree). In the context of a bus driver's job "transferring to another job" and "changing the job itself" inevitably means leaving employment as a bus driver given the lack of scope to engage in "other" work.

\section{Data analysis}


Data collected from the survey were inputted into SPSS for reliability and validity tests. Before testing the hypothesized model, the researchers examined the measurement model, as recommended by Anderson and Gerbing's (1988) two-step approach. The measurement model was performed before the structural model because the measurement model must hold before the test of the hypothesized relationships amongst the constructs (Cheng, 2001). For the measurement and structural models, analysis was conducted using AMOS 6.0 with the covariance matrix and maximum likelihood estimation. Structural equation modeling (SEM) was chosen for hypothesis testing instead of multiple regressions because it is a more sophisticated way of data analysis. SEM provides simultaneous analysis to answer a set of interrelated research questions. The combined analysis of the measurement and the structural model enables the measurement errors of the observed variables to be analyzed as an integral part of the model. The result is a more rigorous analysis of the proposed research model and very often a better methodological assessment tool (Bollen, 1989).

\section{Results}

\section{Construct Reliability and Validity}

In order to examine the reliability of the scales Cronbach's (1951) alpha test was used. The coefficient measures of the item-total correlations below .30 were dropped to maintain the internal consistency (Hair, Anderson, Tatham, \& Black, 1998). As a result, one item in the RO, in the NP, and in the job strain measures was deleted because of its low item-total correlation. The Cronbach's alphas of all constructs were above .70 , as 
shown in Table 1, indicating satisfactory internal consistency (Hair et al., 1998). Convergent validity was tested by examining the factor loadings to see whether the items in a construct converge or load together on a single construct in factor analysis (Fornell \& Larcker, 1981). Thus, convergent validity exists when statistically significant loadings for all items hypothesized to measure a latent variable are found (Hair et al., 1998). Hair et al. (1998) suggest a cut-off of .50 for the factor loadings. The factor loading of all the items were found to be greater than .50 , demonstrating convergent validity of the constructs. Discriminant validity was examined by the average variance extracted (AVE) (Fornell \& Larcker, 1981). Table 2 presents the AVE in exploratory factor analysis in pairs and the squared correlations of all constructs. Discriminant validity exists when AVE is greater than the squared correlation between pairs of factors (Fornell \& Larcker, 1981). The results confirmed discriminant validity of all items. Table 3 shows the means, standard deviations, and correlations of the constructs.

[Insert Table 1 about here]

[Insert Table 2 about here]

[Insert Table 3 about here]

\section{Measurement and structural model analysis}

Prior to testing the structural model, confirmatory factor analysis (CFA) was used to assess the measurement properties of the scales. A five-factor model was tested including 
the items of non-participation, role overload, job strain, organizational commitment, and intent to leave. The measurement model provided an acceptable fit to the data when we considered all of the fit statistics: $\chi^{2}(179 \mathrm{df}, \mathrm{N}=331)=421.29, \mathrm{p}<.001$; goodness of fit index $(\mathrm{GFI})=.90$; adjusted goodness of fit $(\mathrm{AGFI})=.90$; root-mean-square error of approximation $(\mathrm{RMSEA})=.06$; incremental fit index $(\mathrm{IFI})=.94$; normed fit index $(\mathrm{NFI})$ $=.90 ;$ comparative fit index $(\mathrm{CFI})=.94$; non-normed fit index $(\mathrm{NNFI})=.92$. The hypothesized model provided a good fit to the data on the basis of the fit statistics: $\chi^{2}$ $(182 \mathrm{df}, \mathrm{N}=331)=433.45, \mathrm{p}<.001 ; \mathrm{GFI}=.90 ;$ AGFI $=.90 ;$ RMSEA $=.06 ;$ IFI = .93; $\mathrm{NFI}=.90 ; \mathrm{CFI}=.93 ; \mathrm{NNFI}=.92$.

The significant chi-square test result is undesirable but it may be due to the large sample size (Anderson \& Gerbing, 1988; Hair et al., 1998). With an aim to examining the impact of large samples on the chi-square index, two other measure, normed chi-square and standardized root mean square residual (SRMR), were introduced. These two indices were also satisfactory (normed chi-square $=2.35$ for the measurement model, while that for the structural model $=2.38 ;$ SRMR for the measurement model $=.07$, while that for the structural model $=.07$ ), which suggests that the significant chi-square statistics may be caused by the large sample size. Figure 2 shows the fitted model with correlations, the regression coefficients, and the $\mathrm{R}$ square values.

\section{[Insert Figure 2 about here]}

Table 4 summarizes the results of standardized coefficients, t-statistics, and significance level (p-value) of all hypotheses in the model. Five hypotheses achieved statistically 
significant results with p-values less than .001 , while one hypothesis was not supported. Two of the five paths demonstrated negative relationships, while the other three showed positive relationships among the constructs. The standardized coefficients of the five paths range from -0.73 to 0.43 . The two most significant paths are $\mathrm{H} 2$ (non-participation to be a negative determinant of organizational commitment) and $\mathrm{H} 4$ (role overload positively determines intent to leave), with standardized coefficients of -0.73 and 0.43 respectively.

[Insert Table 4 about here]

\section{Discussion}

The central aim of the present study is to investigate the impact of work-related stressors on Australian transit drivers' organizational commitment and intent to leave. As previously discussed, little research attention has been paid to the impact of role stressors on transit drivers' commitment and turnover. The findings show that non-participation has a direct and negative relationship with organizational commitment (standardized beta coefficient being -0.73). Lambert and Hogan (2008) found that input into decision making has a significant positive correlation with organizational commitment, suggesting that participation may increase one's commitment to the organization. Nevertheless, a lower extent of participation may exhibit less commitment to one's organization, which is consistent with the finding of this study. Clearly the commitment of the drivers in this 
study is adversely related to the perception that they are not sufficiently involved in important aspects of their job.

Another finding of the current study is that role overload has a direct and positive relationship with intent to leave (standardized beta coefficient of 0.43 ). This is in line with Jones, Chonko, Rangarajan, and Roberts (2007) who argued that role overload has a significant positive relation with turnover intentions. Lambert and Hogan (2008) found that role overload affects intent to leave through job satisfaction, indicating an indirect relationship between role overload and intent to leave, and thus shows a potential mediation effect between role overload and intent to leave.

In addition to the above findings, non-participation and role overload are found to have significant positive relationships with job strain. Glazer and Beehr (2005) also found that role overload has significant positive correlation with job strain, thus corresponding to the result of this study. However, job strain does not show a significant negative relation with organizational commitment. This denotes that one could feel stressed out by their work, but feeling stressed does not necessarily mean they will leave the organization. Employees may stay with an organization for the salary, for their work title, for the colleagues, or simply because they like the organization. As a result, the findings of the present study suggest that work-related stressors appear to influence organizational commitment and intent to leave directly rather than indirectly through job strain. The implications of this finding are very important for the bus transit industry. We would have expected the findings to show that being under pressure to run to timetable, maintain discipline on school buses, responsibility for the behavior of passengers and isolation due to poor communications would be negatively associated with drivers' 
commitment, given the importance placed on these activities as major elements of bus transit drivers' work as identified by Angle and Perry (1981) and Evans (1994).

\section{Limitations}

The main limitation of the study is its cross-sectional nature, which excludes any causal inferences regarding the relationships tested. Additionally, because data for the independent and dependent variables were collected from the same employees concurrently, common method variance may give rise to a potential problem (Spector, 2006). However, it is hard to imagine that the participants would have artificially caused the differing patterns of relationships between the variables. As a result, common method variance is not considered to be a major concern for this study. Lastly, the sample was drawn by purposive sampling. Generalizability could only be applied to the fourteen bus companies that participated in this study.

\section{Practical implications and future research}

This study shows that non-participation is a strong, negative predictor of organizational commitment for transit drivers; hence, organizations should take employee involvement into consideration when designing jobs for transit drivers. This could be achieved by inviting employee input on how work is organized, which makes employees feel they are being heard by the management, in turn leading to more committed transit drivers. And higher levels of commitment are desirable. Organizations should also keep all levels of employees informed of important messages and/or changes in the company, so that employees feel more involved in the work environment. 
In addition to the above finding, role overload is found to be a strong predictor of intent to leave. Therefore, organizations are urged not to place unreasonable expectations about the quality or quantity of work on transit drivers. This may include less stringent regulations, more flexible timetables and/or rosters, so that transit drivers' intent to leave may be lessened. Moreover, non-participation and role overload are found to have significant positive impacts on job strain. The impact of role stressors and job strain on employee health has been delineated in the extant literature (Bech et al., 2005; Graham et al., 2000; Kelloway \& Barling, 1991; Knudsen et al., 2007). Practitioners may wish to encourage their staff to release work stress by means such as exercise, so that transit drivers could retain their health. Managers may also wish to set up health promotion programs such as to work with the local gym to provide employee discount to encourage employees' workout. Organizations could also hold employee picnics so that workers have a chance to make friends at the workplace.

In order to extend the findings of this study, longitudinal research is needed to assess issues of causality. Alternatively, experimental studies may be conducted to provide evidence of causality. Lastly, replication of the proposed model in a different service context is needed, as generalizability of the results will be reinforced if this is achieved.

\section{Conclusion}

This study examines the relationships between the role-stressors non-participation and work overload, and job strain, commitment and intent to leave. The findings suggest that role overload is an important indicator of job strain and intent to leave. Non-participation 
also contributes to job strain although its most important relationship is a strong negative effect on commitment. An interesting, and unexpected result, was the finding of no significant relationship between job strain and commitment. These findings add to the literature relating to occupational stress experienced by transit operators and have relevance for service organizations seeking to improve organizational effectiveness through higher levels of employee commitment. 


\section{References}

Abdel-Halim, A. (1981). Effects of role stress, job design, technology, interaction on employee work satisfaction. Academy of Management Journal, 24(2), 260-273.

Addae, H., Parboteeah, K., \& Velinor, N. (2008). Role stressors and organizational commitment: public sector employment in St Lucia. International Journal of Manpower, 29(6), 567-582.

Anderson, J. C., \& Gerbing, D. W. (1988). Structural equation modeling in practice: A review and recommended two-step approach. Psychological Bulletin, 103(3), 411-423.

Angle, H., \& Perry, J. (1981). An empirical assessment of organizational commitment and organizational effectiveness. Administrative Science Quarterly, 26(1), 1-14.

Barnard, C. (1938). The functions of the executive. Boston: Harvard University Press.

Bech, P., Andersen, M., Bech-Andersen, G., Tonnesen, S., Agnarsdottir, E., \& Borg, V. (2005). Work-related stressors, depression and quality of life in Danish managers. European Psychiatry, 20, 318-325.

Beehr, T., Walsh, J., \& Taber, T. (1976). Relationship to stress ro individually and organizationally valued states: Higher order needs as a moderator. Journal of Applied Psychology, 61(1), 41-47.

Bollen, K. (1989). Structural equations with latent variables. New York: John Wiley and Sons.

Broadbridge, A. (2002). Retail managers: Their work stressors and coping strategies. Journal of Retailing and Consumer Services, 9, 173-183.

Cappelli, P. (1999). The new deal at work. Boston: Harvard Business School Press.

Carrere, S., Evans, G., Palsane, M., \& Rivas, M. (1991). Job strain and occupational stress among urban public transit operators. Journal of Occupational Psychology, 64(4), 305-317.

Chang, S.-I. (2008). Work role stressors and turnover intentions: A study of IT personnel in South Korea. Zeitschrift fur Personalforschung, 22(3), 272-290.

Chen, M., \& Cunradi, C. (2008). Job stress, burnout and substance use among urban transit drivers: The potential mediating role of coping behaviour. Work and Stress, 22(4), 327-340.

Cheng, E. (2001). SEM being more effective than multiple regression in parsimonious model testing for management development research. Journal of Management Development, 20(7), 650-667.

Cooper, C. (1983). Identifying stressors at work: Recent research developments. Journal of Psychosomatic Research, 27(5), 369-376.

Cronbach, L. (1951). Coefficient alpha and the internal structure of tests. Psychometrika, 16, 297-334.

Dale, K., \& Fox, M. L. (2008). Leadership style and organizational commitment: Mediating effect of role stress. Journal of Managerial Issues, 20(1), 109-130.

de Ruyter, K., Wetzels, M., \& Feinberg, R. (2001). Role stress in call centers: Its effects on employee performance and satisfaction. Journal of Interactive Marketing, 15(2), 23-35. 
DeCotiis, T. A., \& Summers, T. P. (1987). A path analysis of a model of the antecedents and consequences of organizational commitment. Human Relations, 40(7), 445470.

Dubinsky, A., Michaels, R., Kotabe, M., Lim, C., \& Moon, H. (1992). Influence of role stress on industrial salespeople's work outcomes in the United States, Japan and Korea. Journal of International Business Studies, 23(1), 77-100.

Etzioni, A. (1961). A basis for comparative analysis of complex organizations. In A. Etzioni (Ed.), A sociological reader on complex organizations. New York: Holt, Rinehart \& Winston.

Evans, G. (1994). Working on the hot seat: Urban bus operators. Accidient Analysis and Prevention, 26(2), 181-193.

Evans, G., Johansson, G., \& Rydstedt, L. (1999). Hassles on the job: A study of job intervention with urban bus drivers. Journal of Organizational Behavior, 20, 199208.

Fornell, C., \& Larcker, D. F. (1981). Evaluating structural equation models with unobservable variables and measurement error. Journal of Marketing Research, 18(1), 39-50.

Gardell, B. (1987). Efficiency and health hazards in mechanized work. In J. Dalton \& J. Quick (Eds.), Work stress. New York: Praeger.

Glazer, S., \& Beehr, T. (2005). Consistency of implications of three role stressors across four countries. Journal of Organizational Behavior, 26, 467-487.

Goedhard, R., \& Goedhard, W. (2005). Work ability and perceived work stress. International Congress Series, 79-83.

Graham, J., Ramirez, A., Field, S., \& Richards, M. (2000). Job stress and satisfaction among clinical radiologists. Clinical Radiology, 55, 182-185.

Greiner, B., Krause, N., Ragland, D., \& Fisher, J. (2004). Occupational stressors and hypertension: A multi-method study using observer-based job analysis and selfreports in urban transit operators. Social Science and Medicine, 59, 1081-1094.

Greiner, B., Ragland, D., Krause, N., Syme, S., \& Fisher, J. (1997). Objective measurement of occupational stress factors: An example with San Francisco urban transit operators. Journal of Occupational Health Psychology, 2(4), 325342.

Guest, D. (1998). Beyond HRM: Commitment and the contract culture. In P. Sparrow \& M. Marchington (Eds.), Human resource management: The new agenda. London: Pitman Publishing.

Hair, J. F., Jr., Anderson, R. E., Tatham, R. L., \& Black, W. C. (1998). Multivariate data analysis (5th ed.). New Jersey: Prentice Hall.

Harris, E., Artis, A., Walters, J., \& Licata, J. (2006). Role stressors, service worker job resourcefulness, and job outcomes: An empirical analysis. Journal of Business Research, 59, 407-415.

Indik, B., Seashore, S., \& Slesinger, J. (1964). Demographic correlates of psychological strain. Journal of Abnormal and Social Psychology, 69, 26-38.

Jones, E., Chonko, L., Rangarajan, D., \& Roberts, J. (2007). The role of overload on job attitudes, turnover intentions, and salesperson performance. Journal of Business Research, 60, 663-671. 
Kahn, R., Wolfe, D., Quinn, R., Snoek, J., \& Rosenthal, R. (1964). Organizational stress: Studies in role conflict and ambiguity. New York: Wiley.

Karasek, R. (1979). Job demands, job decision latitude, and mental strain: Implications for job design. Administrative Science Quarterly, 24, 285-308.

Kelloway, E., \& Barling, J. (1991). Job characteristics, role stress and mental health. Journal of Occupational Psychology, 64, 291-304.

Knudsen, H., Ducharme, L., \& Roman, P. (2007). Job stress and poor sleep quality: Data from an American sample of full-time workers. Social Science and Medicine, 64, 1997-2007.

Lambert, E., \& Hogan, N. (2008). The importance of job satisfaction and organizational commitment in shaping turnover intent: A test of a causal model. Criminal Justice Review, 34(1), 96-118.

March, J., \& Simon, H. (1958). Organizations. New York: Wiley.

McGrath, J. (1976). Stress and behavior in organizations. Chicago: Rand McNally.

Meyer, J., Becker, T., \& Henkin, A. (2004). Employee commitment and motivation: A conceptual analysis and integrative model. Journal of Small Business Management, 35, 39-67.

Mulki, J. P., Jaramillo, J. F., \& Locander, W. B. (2008). Effect of ethical climate on turnover intention: Linking attitudinal- and stress theory. Journal of Business Ethics, 78, 559-574.

Penley, L., \& Gould, S. (1988). Etzioni's model of organizational involvement: A perspective for understanding commitment to organizations. Journal of Organizational Behevior, 9, 43-59.

Pettegrew, L., Thomas, R., Costello, D., Wolf, G., Lennoz, L., \& Thomas, S. (1980). Job related stress in a medical center organization: Management of communication issues. In D. Nimmo (Ed.), Communication yearbook. New York: Transaction Books.

Qiang, T., Ragunathan, B., \& Ragunathan, T. (2001). A path analytic study of the antecedents of organizational commitment of IS managers. Information Resources Management Journal, 14(3), 27-36.

Richardson, H. A., Yang, J., Vandenberg, R. J., DeJoy, D. M., \& Wilson, M. G. (2008). Perceived organizational support's role in stressor-strain relationships. Journal of Managerial Psychology, 23(7), 789-810.

Rydstedt, L., Johansson, G., \& Evans, G. (1998). A longitudinal study of workload, health and well-being among male and female urban bus drivers. Journal of Occupational and Organizational Psychology, 71, 35-45.

Schaubroeck, J., Cotton, J., \& Jennings, K. (1989). Antecedents and consequences of role stress: A covariance structure analysis. Journal of Organizational Behavior, 10, 35-58.

Seyle, H. (1974). Stress without distress. Philadelphia: Lippincott.

Spector, P. (2006). Method variance in organizational research: Truth or urban legend? Organizational Research Methods, 9, 221-232.

Spector, P., Chen, P., \& O'Connell, B. (2000). A longitudinal study of relations between job stressors and job strains while controlling for prior negative affectivity and strains. Journal of Applied Psychology, 85(2), 211-218. 
Steers, R. M. (1977). Antecedents and consequences of organizational commitment. Administrative Science Quarterly, 22, 46-56.

Warren, E., \& Toh, C. (1997). The stress work book. London: Nicholas Brealey.

Weisberg, J. (1994). Measuring workers' burnout and intention to leave. International Journal of Manpower, 15(1), 4-15.

Yousef, D. (2002). Job satisfaction as a mediator of the relationship between role stressors and organizational commitment. Journal of Managerial Psychology, 17(4), 250-266. 
Table 1 Reliability test results

\begin{tabular}{|c|c|}
\hline Item & Loading \\
\hline \multicolumn{2}{|l|}{ Role overload (reliability $=.79)$} \\
\hline RO1 I find that I have extra work beyond what should normally be expected & .61 \\
\hline RO2 I feel under pressure from others to improve the quality of my work & .51 \\
\hline RO3 The performance standards on my job are too high & .66 \\
\hline RO4 I have too many responsibilities in my job & .65 \\
\hline \multicolumn{2}{|l|}{ Non-participation (reliability $=.78$ ) } \\
\hline NP1 I am not kept informed of important things happening in this company & .62 \\
\hline $\begin{array}{l}\text { NP2 I feel it is useless to make suggestions about my work because nobody } \\
\text { listens to them }\end{array}$ & .54 \\
\hline NP3 I am not interested in the many changes taking place at work & .54 \\
\hline NP4 I have no influence over what goes on in my company & .66 \\
\hline \multicolumn{2}{|l|}{ Job strain (reliability $=.87)$} \\
\hline Strain1 I am bothered by being under pressure to run to timetable & .72 \\
\hline Strain2 I am bothered by having to maintain discipline on school buses & .76 \\
\hline Strain3 I am bothered by being responsible for the behavior of passengers & .79 \\
\hline $\begin{array}{l}\text { Strain } 4 \text { I am bothered by the need for better means of communicating with my } \\
\text { base }\end{array}$ & .60 \\
\hline \multicolumn{2}{|l|}{ Organizational commitment $($ Moral commitment $)($ reliability $=.89)$} \\
\hline OCS3 I am dedicated to this company & .73 \\
\hline OCS6 I feel it is my duty to support this company & .81 \\
\hline $\begin{array}{l}\text { OCS9 Whenever I am in public I think of myself as an employee of this } \\
\text { company }\end{array}$ & .66 \\
\hline OCS12 It is my personal responsibility to help this company achieve success & .76 \\
\hline OCS15 I get upset when people say bad things about this company & .67 \\
\hline \multicolumn{2}{|l|}{ Intent to leave (reliability $=.88$ ) } \\
\hline Leave1 How frequently did you consider transferring to some other job & .82 \\
\hline Leave2 How frequently did you consider changing the job itself & .79 \\
\hline $\begin{array}{l}\text { Leave } 3 \text { How frequently did you consider wanting to renegotiate } \\
\text { responsibilities }\end{array}$ & .66 \\
\hline Leave4 How frequently did you consider threatening to leave & .70 \\
\hline
\end{tabular}


Table 2 Discriminant validity test using AVE and correlation methods

\begin{tabular}{|l|c|c|c|c|c|}
\hline Construct & Non-participation & Role overload & Job strain & $\begin{array}{c}\text { Organizational } \\
\text { commitment }\end{array}$ & Intent to leave \\
\hline Non-participation & - & $64 \%$ & $67 \%$ & $66 \%$ & $69 \%$ \\
\hline Role overload & .17 & - & $68 \%$ & $66 \%$ & $70 \%$ \\
\hline Job strain & .21 & .20 & - & - & $71 \%$ \\
\hline $\begin{array}{l}\text { Organizational } \\
\text { commitment }\end{array}$ & .32 & .17 & .08 & & \\
\hline Intent to leave & .19 & .29 & .16 & & -31 \\
\hline
\end{tabular}

Note: The upper diagonal shows AVE results, while the lower shows squared correlations of the constructs

Table 3 Means, standard deviations, and correlations among the variables $(n=331)$

\begin{tabular}{|l|c|c|c|c|c|c|c|}
\hline & Mean & SD & 1 & 2 & 3 & 4 \\
\hline $\begin{array}{c}\text { 1 Non- } \\
\text { participation }\end{array}$ & 3.37 & 1.17 & 1 & & & \\
\hline 2 Role overload & 2.39 & 1.13 & $.41^{* *}$ & 1 & & \\
\hline 3 Job strain & 2.61 & 1.61 & $.46^{* *}$ & $.45^{* *}$ & 1 & \\
\hline $\begin{array}{c}4 \text { Organizational } \\
\text { commitment }\end{array}$ & 3.57 & 1.19 & $-.57^{* *}$ & $-.41^{* *}$ & $-.29^{* *}$ & 1 & \\
\hline 5 Intent to leave & 2.43 & 1.30 & $.44^{* *}$ & $.54^{* *}$ & $.40^{* *}$ & $-.56^{* *}$ & 1 \\
\hline
\end{tabular}

Note: $* * \mathrm{p}<0.01$ (two-tailed) 
Table 4 Path hypothesis confirmation

\begin{tabular}{|l|l|l|}
\hline Model hypotheses & \multicolumn{1}{|c|}{ Results } \\
\hline $\begin{array}{l}\text { H1. Non-participation is a positive determinant } \\
\text { of job strain }\end{array}$ & $\begin{array}{l}\text { Coefficient } \\
\text { Critical ratio } \\
\text { Significant? }\end{array}$ & $\begin{array}{l}0.29 \\
3.65(\mathrm{p}<.001) \\
\text { Significant }\end{array}$ \\
\hline $\begin{array}{l}\text { H2. Non-participation is a negative determinant } \\
\text { of organizational commitment }\end{array}$ & $\begin{array}{l}\text { Coefficient } \\
\text { Critical ratio } \\
\text { Significant? }\end{array}$ & $\begin{array}{l}-0.73 \\
-9.06(\mathrm{p}<.001) \\
\text { Significant }\end{array}$ \\
\hline $\begin{array}{l}\text { H3. Role overload is a positive determinant of } \\
\text { job strain }\end{array}$ & $\begin{array}{l}\text { Coefficient } \\
\text { Critical ratio } \\
\text { Significant? }\end{array}$ & $\begin{array}{l}0.34 \\
4.24(\mathrm{p}<.001) \\
\text { Significant }\end{array}$ \\
\hline $\begin{array}{l}\text { H4. Role overload is a positive determinant of } \\
\text { intent to leave }\end{array}$ & $\begin{array}{l}\text { Coefficient } \\
\text { Critical ratio } \\
\text { Significant? }\end{array}$ & $\begin{array}{l}0.43 \\
7.02(\mathrm{p}<.001) \\
\text { Significant }\end{array}$ \\
\hline $\begin{array}{l}\text { H5. Job strain is a negative determinant of } \\
\text { organizational commitment }\end{array}$ & $\begin{array}{l}\text { Coefficient } \\
\text { Critical ratio } \\
\text { Significant? }\end{array}$ & $\begin{array}{l}0.06 \\
0.98 \text { (p }=.326) \\
\text { Non-significant }\end{array}$ \\
\hline $\begin{array}{l}\text { H6. Organizational commitment is a negative } \\
\text { determinant of intent to leave }\end{array}$ & $\begin{array}{l}\text { Coefficient } \\
\text { Critical ratio } \\
\text { Significant? }\end{array}$ & $\begin{array}{l}-0.43 \\
-7.73 \text { (p }<.001) \\
\text { Significant }\end{array}$ \\
\hline
\end{tabular}


Figure 1 Hypothesized relationships between the constructs

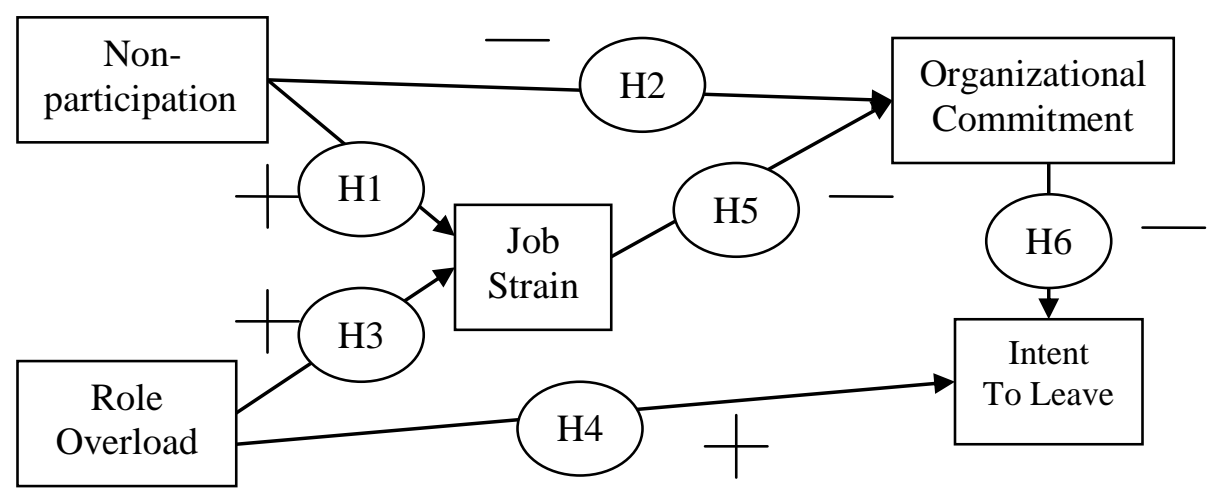


Figure 2 Maximum likelihood estimates for the hypothesized model

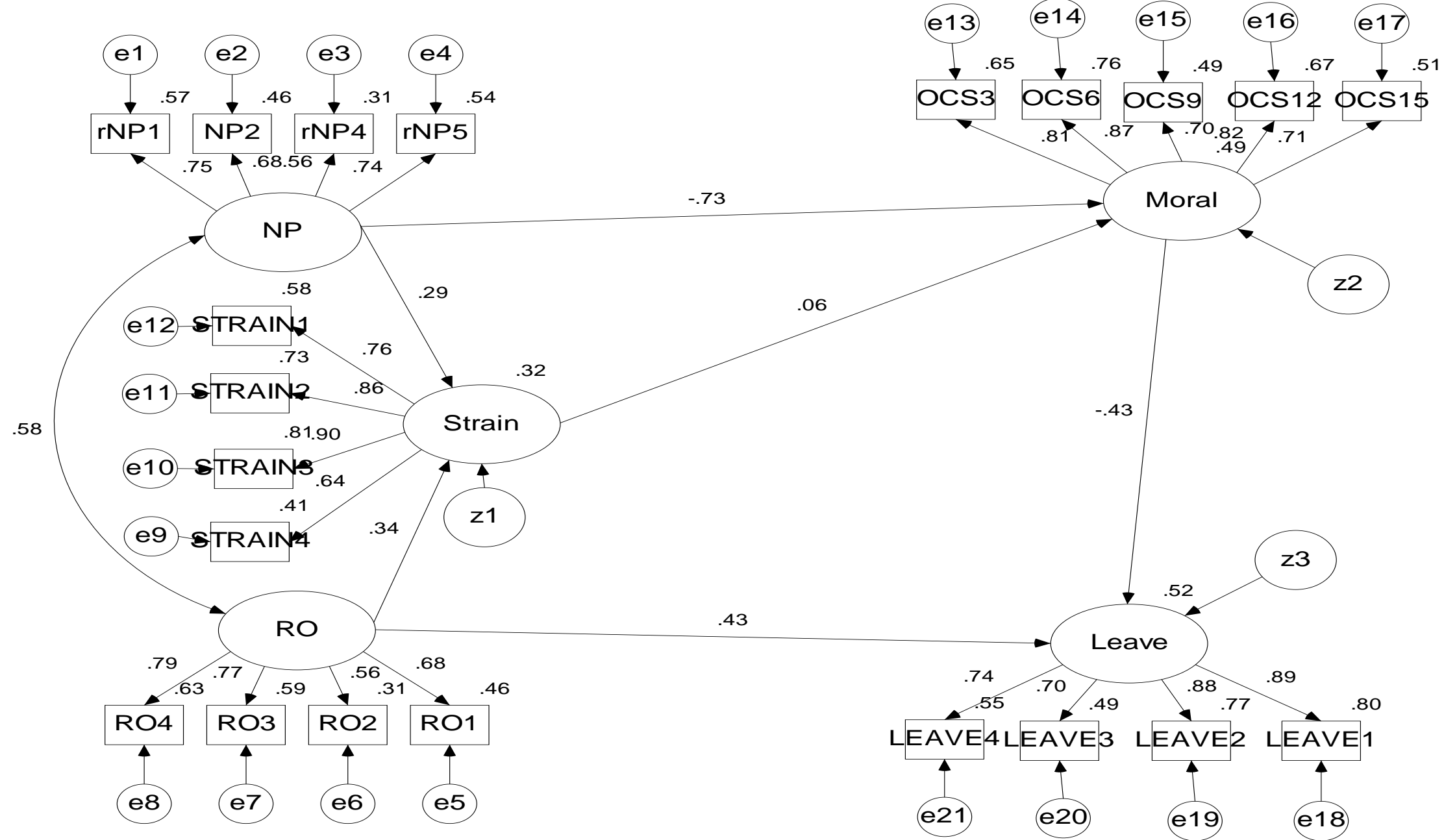

Note: NP=Non-participation; RO=Role overload; Strain=Job strain; Moral=Organizational commtiment; Leave=Intent to leave. 